ISSN 1392-3196 / e-ISSN 2335-8947

Zemdirbyste-Agriculture, vol. 103, No. 2 (2016), p. 215-220

DOI $10.13080 /$ z-a.2016.103.028

\title{
Influence of 1-MCP treatment and storage conditions on the development of microorganisms on the surface of apples grown in Latvia
}

\author{
Karina JUHNEVICA-RADENKOVA, Vitalijs RADENKOVS, Dalija SEGLINA \\ Institute of Horticulture, Latvia University of Agriculture \\ Graudu 1, Dobele, Latvia \\ E-mail: karina.juhnevica@lvai.lv
}

\begin{abstract}
The quality of fruits during storage depends on the storage environment and fruit microorganisms, since the activity of microorganisms can cause the decay of fruits. A correctly selected composition of gas mixture in a storage chamber extends shelf-life by reducing development of microorganisms, accordingly ensuring microbiological safety of fruits. The aim of the study was to evaluate the dynamics of microflora on the surface of apples within six months of cold storage that prior to storage had been treated with 1-methylcyclopropene (1-MCP), and those stored in ultra low oxygen (ULO) under different controlled atmosphere conditions. The highest microbial diversity and amount on the apple fruit surface was found when stored in cold storage. At the beginning of storage, $70 \%$ of the total surface microflora of fruits consisted of the following microscopic fungi: Penicillium spp., Alternaria spp., Botrytis spp., Aspergillus spp., Mucor genus and Cladosporium spp., bacteria from Bacillus genus, and yeasts like Candida curvata, C. fomata, Pichia etchellsii and P. carsonii. After three and six months of apple storage, partial microorganism inhibition was observed when comparing cold storage and cold storage +1 -MCP treatments, in turn, the most positive significant result was achieved when apples were stored under controlled atmosphere conditions.

After six months of apple storage, the lowest amount of colony forming units (CFU) of bacteria, mould and yeast was estimated on the surface of apple fruits that had been stored using controlled atmosphere technique. Microorganisms, including Penicillium, Bacillus spp., Candida curvata, Pichia etchellsii and C. fomata were identified on the surface of ULO1 samples, while on ULO2 samples only Penicillium spp., Bacillus spp., C. curvata and C. fomata. After storage in controlled atmosphere, $90 \%$ of all microscopic fungi present on the surface of apples were yeasts.
\end{abstract}

Key words: controlled atmosphere, microorganisms, storage technologies, surface.

\section{Introduction}

Fruit quality during storage mainly depends on the fruit microflora and microbial activity. Microorganisms in appropriate conditions can cause fruit decay, leading to reduction of fruit quality (Barth et al., 2009).

Microflora of apples is very diverse, since fruits present nearly ideal conditions for the survival and growth of many types of microorganisms. Typical apple microflora is various microorganism species of microscopic fungi: (Penicillium spp., Botrytis spp., Alternaria spp., Aspergilus spp., Cladosporium spp., Geotrichum spp., Fusarium spp., Eurotium spp., Wallemia spp. and Trichoderma spp.), yeasts (Candida, Pischia, Saccharomyces, Zygosaccharomyces, Hanseniaspora and Debaryomyces), as well as bacteria (Bacillus spp.) (Barta, 2006). These microorganisms predominantly occur on the apple surface, but the frequency and share of colonisation can vary. Fresh apple skin with active substances, natural wax coating and its firmness act as a barrier and microbes are restrained to remain outside of fruit flesh as long as the skin is healthy and intact (Barta, 2006; Rodrigo et al., 2012).

The first apple contamination with the microscopic fungi Botrytis spp., Fusarium spp., Trichothecium spp., Alternaria spp., Penicillium spp., Monilinia spp. and others may occur during crop growth in the field. Most of the mentioned microscopic fungi belong to the normal fruit microflora, but often in suitable environment conditions (high level of relative humidity and temperature) at specific fruit ripening stage cause apple spoilage. Contamination occurs predominantly during the growing season and the main contamination sources are apple residues, damaged apples, infected branches and shoots. For instance, if the tree is infected with Neonectria galligena, then after harvesting there is a high risk that apples will be also contaminated with these fungi, which leads to apple spoilage (Beresford, Kim, 2011). The second phase for risk of contamination is apple harvesting time, when they come in contact with 
soil, during transportation and further processing and handling (Oranusi, Wesley, 2012).

If apple are collected with soiled hands or after harvesting washed with water whose quality does not conform to hygiene requirements, the fruits can be contaminated with Enterobacter, Shigella, Salmonella spp., Vibrio cholerae, Cryptosporidium parvum, Giardia lamblia, Cyclospora caytanensis, Toxiplasma gondii, E. coli $0157: \mathrm{H7}$, etc., that can cause both fruit spoilage and human poisoning (Barta, 2006). Apples, which have fallen to the ground, can be contaminated with bacteria Listeria monocytogenes and Sarcina spp. In both phases (growing and harvesting), apple surface can be contaminated with soil particles that contain a wide range of soil-born aerobic and anaerobic forms of endospores of Bacillus spp. and Clostridium spp., as well as various yeast species.

Active acidity $(\mathrm{pH})$ of cell juice, water activity, relative air humidity, temperature, storage environment, and osmotic pressure determine the intensity of microorganism development. The $\mathrm{pH}$ value of fresh apples varies from 2.9 to 3.3 (Lampel et al., 2012), while for most bacteria such $\mathrm{pH}$ is not suitable. The optimum $\mathrm{pH}$ for growth of most bacteria is close to neutral (6-8). However, yeasts and moulds are usually acid-tolerant and therefore associated with the spoilage of acidic foods. Microscopic fungi grow in slightly acidic $\mathrm{pH}$ 5.0, while yeasts can grow in a $\mathrm{pH}$ range of 4.5 to 5.5 . The genera of lactic acid bacteria include Lactobacillus, Leuconostoc, Streptococcus and some gram-positive pathogenic bacteria such as Clostridium also called as acidophiles and alkaliphiles bacteria that can grow at extreme $\mathrm{pH}$ media. For instance, Bacillus genera can be attributed to alkaliphiles bacteria that usually occur on apples (Juhneviča et al., 2011).

It is well known that water is important for cells, microorganism existence and development; furthermore, the amount of water depends on the specific microorganism genera (Tapia et al., 2007). Pure water activity is 1.0 , but in fresh fruits water activity is slightly lower and corresponds to 0.99 . These characteristics make fruit more suitable for the growth of most microorganisms both Gram positive and Gram-negative bacteria. Gram-positive bacteria are very sensitive to changes in water activity. If water activity is too low, for instance $0.75-0.61$, halophilic bacteria, xerophilic microscopic fungi and osmophilic yeasts multiplication can occur (Barta, 2006).

Properly chosen relative humidity in storerooms extends the shelf-life of fruit due to prevention of water losses throughout storage. During fruit storage, adequate control of relative humidity reduces the rate of water loss, maintains water activity at a high level, thereby negatively affecting microorganism development. Advisable relative humidity in storage chambers is 85 $95 \%$, depending on the type of commodities. During storage, relative humidity in storage chambers should be controlled. When the humidity is insufficient, a water loss is more pronounced and it leads to softening process, resulting in the decline in fruit quality. In turn, when water activity is too high, the risk of microorganism development increases (Henney et al., 2010).

Storage temperature is another major extrinsic factor that strongly influences the microorganism development. Advisable storage temperature for most of apples is from +2 to $+4^{\circ} \mathrm{C}$ depending on the cultivar. Additionally, the content of oxygen in storage chambers has also great influence on the development of microorganisms. For instance, aerobic bacteria well grow in the presence of oxygen, especially when the concentration of oxygen is close to atmospheric $21 \%$.

Subsequently, aerobic bacteria divide into: obligate aerobes that require oxygen for growth, facultative aerobes that grow well in partial presence of oxygen, as well as without it and microaerophilic members of this group can grow under reduced oxygen $(5 \%$ to $10 \%)$ and increased carbon dioxide presence $(8 \%$ to $10 \%$ ). Anaerobe microorganisms that do not require oxygen for growth can be divided into: facultative anaerobes that do not use oxygen, but they can grow both in aerobe as well as anaerobe conditions and obligate anaerobe. Obligate anaerobe microorganisms are oxygen sensitive, grow only under reduced oxygen conditions. Hence, storage in controlled atmosphere (with reduced oxygen) has a great advantage because it substantially reduces the possible development of spores as well as limits the probable infection of healthy apples (Juhneviča et al., 2011). In turn, it is well known that treatment of climacteric fruits with ethylene inhibitor 1-MCP allows significantly delay the ripening processes, which are associated with biochemical and physiological changes. Since unambiguous researches about the impact of 1-MCP on microbial growth have not yet been observed, it is important to ascertain the impact of 1-MCP on microbial growth. Therefore, the aim of the study was to evaluate the dynamics of microflora on the surface of apples, prestorage treated with 1-methylcyclopropene (1-MCP), within six months of cold storage and on those stored in ultra low oxygen (ULO) under different controlled atmosphere conditions.

\section{Material and methods}

The studies took place in 2012 and 2013 at the Experimental Processing Department of the Latvia State Institute of Fruit-Growing (currently - Institute of Horticulture, Latvia University of Agriculture) in Dobele and at the Laboratory of Microbiology of the Faculty of Food Technology in the Latvia University of Agriculture. In each harvesting year, the duration of experiment was six months. Analyses were carried out before apple storage, then after three and six months of storage. One apple commercial cultivar 'Auksis', grown in the orchard of the Institute, was used.

Shortly after harvesting, apples were air-cooled for 24 hours in a cooling chamber at up to $+4 \pm 0.5^{\circ} \mathrm{C}$ temperature. From the selected cultivar 'Auksis' 40 fruits were sampled, their average mass was $\sim 6 \mathrm{~kg}$. For each storage technology, the same weight of apples was prepared. Then the samples were placed in a polypropylene boxes with perforated walls. The total number of boxes was twelve. The cooled down apple samples were divided into four groups for post-harvest storage: 1) cold storage - control, apples were stored under traditional conditions at air temperature $+2 \pm 1^{\circ} \mathrm{C}$ and relative air humidity of $85 \%$; 2) cold storage +1 -methylcyclopropene (1-MCP) treatment; 3) ultra low oxygen (ULO1) - $\mathrm{O}_{2} 1.00 \%$, $\mathrm{CO}_{2} 2.00 \%$; 4) ULO2 - $\mathrm{O}_{2} 1.50 \%, \mathrm{CO}_{2} 2.50 \%$. Storage in ULO was implemented in Fruit Control Equipment (Italy) by selecting two different gas compositions in the mixture of controlled atmosphere. 
The treatment with ethylene inhibitor 1-MCP was performed in a air-tight fruit processing container. The ethylene action inhibitor 1-methylcyclopropene was purchased from RandH: Rohm and Haas Company (Italy). The material consists of a homogeneous mixture of $1-\mathrm{MCP}$ at a concentration of $3.3 \%$ together with related manufacturing impurities, in the form of a complex with alpha-cyclodextrin, together with any other necessary coformulants.

$1-\mathrm{MCP}$ powdery substance was dissolved in warm water $+50 \pm 2{ }^{\circ} \mathrm{C}$ by ratio of $1-\mathrm{MCP}$ to water as $1: 30$, the concentration of the obtained solution was $0.625 \mathrm{ml} \mathrm{L}^{-1}$. This ratio was selected on the well-founded scientific research of Polish researchers affirming abovementioned concentration as more suitable for apple treatment with 1-MCP (Wawrzynczak et al., 2007). The solution was prepared in an Erlenmeyer flask, which was subsequently placed in an air-tight processing container with apples intended for storage.

Based on 1-MCP manufacturer's (RandH, Italy) recommendations in room capacity of $0.5 \mathrm{~m}^{3}$ the amount of 1 -MCP preparation could be $0.5 \mathrm{~g}$. The treatment with 1 -MCP was performed at a temperature of $18 \pm 1{ }^{\circ} \mathrm{C}$ in an air-tight fruit processing container for $24 \mathrm{~h}$. After treatment, fruit samples were stored in cold storage under traditional conditions. The apples treated with 1-MCP and untreated (control) were stored at the same conditions but on different pallets.

The microbiological analysis of air in ULO chambers and cooled store-room was carried out in accordance with LVS EN 13098:2001 standard Workplace atmospheres - Guidelines for measurement of airborne micro-organisms and endotoxin.

Microflora of apple surface was determined in accordance with LVS ISO 18593:2007 standard Microbiology of food and animal feeding stuffs - Horizontal methods for sampling techniques from surfaces using contact plates and swabs. The microbiological analyses were carried out in accordance with the following reference methods: for detection of mesophilic aerobic and anaerobic micro-organisms were used standard LVS EN ISO 4833-2:2014 Microbiology of food chain - Horizontal method for the enumeration of microorganisms. Part 2: Colony count at 30 degrees $\mathrm{C}$ by the surface plating technique (ISO 4833-2:2013).
Yeasts and moulds were determined in accordance with standard LVS ISO 21527-1:2008 Microbiology of food and animal feeding stuffs - Horizontal method for the enumeration of yeasts and moulds. Part 1: Colony count technique in products with water activity greater than 0.95. Pseudomonas spp. was determined in accordance with standard LVS EN ISO 16266:2008 Water quality Detection and enumeration of Pseudomonas aeruginosa - Method by membrane filtration. Microscopic fungi were identified in accordance with the method provided by the group of scientists (Juhneviča et al., 2011).

Identification of yeasts was performed using strips of biochemical test-system API - yeasts with API $20 \mathrm{C}$ AUX and ID32 C, but bacteria with API 50 CHB.

The processing of data was carried out by the methods of mathematical statistics, where arithmetic average value of results, standard deviation and standard error were calculated using software Microsoft Excel 2007. Significant differences between the samples were calculated and analysed by the SPSS 20.0, using a two-factor analysis of variance (ANOVA), LSD test and Tukey's test. The significance of differences was determined at $p<0.05$.

\section{Results and discussion}

Air microflora in a storage room is crucial because it is influenced by the microflora and quality of the products. Therefore, in the current study the analysis of initial air microflora in ULO chambers, as well as cooled store-room was carried out and colony forming units of bacteria, yeast and mould were determined (Table). The air contains organic and inorganic mixture of particles, which is combined with dust. Due to pollution, the air can be considered as a source of pathogenic microorganisms, which can cause allergic reactions, respiratory problems and generally adversely affect the human health (Lignell et al., 2007; Karvala et al., 2008; Łukaszuk et al., 2015).

The following microbiological agents can be present in the air: Alternaria spp., Cladosporium spp., Penicillium spp. and Aspergillus spp., bacteria Bacillus spp., Clostridium spp., Streptomycineae spp., Micrococcus spp. and Corynebacterium spp., but yeasts Candida were general representatives (Aithal, 2009). Some of these microorganism species such as Aspergillus,

Table. The dynamics of microflora $\left(\mathrm{CFU} \mathrm{m}{ }^{-3}\right)$ in the apple storage environment during the study period

\begin{tabular}{|c|c|c|c|c|c|c|}
\hline \multirow[b]{2}{*}{ Storage technology } & \multicolumn{3}{|c|}{ 2012-2013 } & \multicolumn{3}{|c|}{ 2013-2014 } \\
\hline & $\begin{array}{l}\text { before } \\
\text { storage }\end{array}$ & $\begin{array}{c}\text { during } \\
3 \text { months } \\
\text { of storage }\end{array}$ & $\begin{array}{c}\text { during } \\
6 \text { months } \\
\text { of storage }\end{array}$ & before storage & $\begin{array}{c}\text { during } \\
3 \text { months } \\
\text { of storage }\end{array}$ & $\begin{array}{c}\text { during } \\
6 \text { months } \\
\text { of storage }\end{array}$ \\
\hline \multicolumn{7}{|c|}{ Yeasts } \\
\hline Cold storage & $9 \mathrm{a}$ & $12 \mathrm{a}$ & $13 \mathrm{a}$ & $8 \mathrm{a}$ & $10 \mathrm{a}$ & $15 \mathrm{a}$ \\
\hline ULO1 & $4 \mathrm{~b}$ & $6 \mathrm{~b}$ & $5 \mathrm{~b}$ & $3 \mathrm{~b}$ & $7 \mathrm{~b}$ & $5 \mathrm{~b}$ \\
\hline ULO2 & $3 \mathrm{~b}$ & $4 \mathrm{~b}$ & $5 \mathrm{~b}$ & $3 \mathrm{~b}$ & $5 \mathrm{~b}$ & $3 \mathrm{~b}$ \\
\hline \multicolumn{7}{|c|}{ Moulds } \\
\hline Cold storage & $12 \mathrm{a}$ & $22 \mathrm{a}$ & $31 \mathrm{a}$ & $11 \mathrm{a}$ & $19 a$ & $33 a$ \\
\hline ULO1 & $6 \mathrm{~b}$ & $4 \mathrm{~b}$ & $5 \mathrm{~b}$ & $4 \mathrm{~b}$ & $3 \mathrm{~b}$ & $5 \mathrm{~b}$ \\
\hline ULO2 & $5 \mathrm{~b}$ & $2 \mathrm{~b}$ & $3 \mathrm{~b}$ & $2 \mathrm{~b}$ & $2 \mathrm{~b}$ & $4 \mathrm{~b}$ \\
\hline \multicolumn{7}{|c|}{ Mesophilic aerobic bacteria } \\
\hline Cold storage & $10 \mathrm{a}$ & $13 \mathrm{a}$ & $15 \mathrm{a}$ & $9 \mathrm{a}$ & $12 \mathrm{a}$ & $18 \mathrm{a}$ \\
\hline ULO1 & $5 \mathrm{~b}$ & $5 \mathrm{~b}$ & $4 \mathrm{~b}$ & $4 \mathrm{~b}$ & $6 \mathrm{~b}$ & $4 \mathrm{~b}$ \\
\hline ULO2 & $4 \mathrm{~b}$ & $3 \mathrm{~b}$ & $4 \mathrm{~b}$ & $3 \mathrm{~b}$ & $4 \mathrm{~b}$ & $2 \mathrm{~b}$ \\
\hline
\end{tabular}

Notes. The different letters in the same column represent significant differences between values by the least significant difference. The mean difference is significant at the 0.05 level. CFU - colony forming unit, ULO - ultra low oxygen. 
Penicillium and Alternaria attack fruits during growth, harvesting or further processing. Mycotoxin production mainly depends on the microorganism growth intensity and storage conditions. If conditions are favourable for fungal growth during fruit storage, the concentration of mycotoxins will be increased. Mycotoxins produced in the host tissues may be aflatoxin, ochratoxin A, patulin and Alternaria toxins. Some of these mycotoxins are known to be carcinogenic - those are very stable during storage and processing and, therefore, can reach the consumer. If the fruits are visually rotten, consumers refuse to buy such fruits; however, processed fruit products may still contain virulent agents that can pose a serious threat to human and animal health (Battilani et al., 2008).

The development of bacteria was most intensive on the surface of 'Auksis' apples, which were stored in cold storage for six months (Fig. 1) The total plate count of bacteria was 435 CFU cm$~_{-2}$ (storage year 2012-2013)

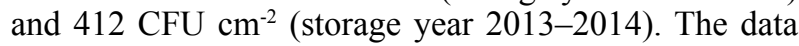
obtained after storage of apples for six months in cold storage $+1-\mathrm{MCP}$ treatment evidenced that the total plate count was $404 \mathrm{CFU} \mathrm{cm}^{-2}$ in storage year 2012-2013, while in storage year 2013-2014 it was 356 CFU cm-2. There were significant differences in CFU between the years (2012-2013 and 2013-2014).

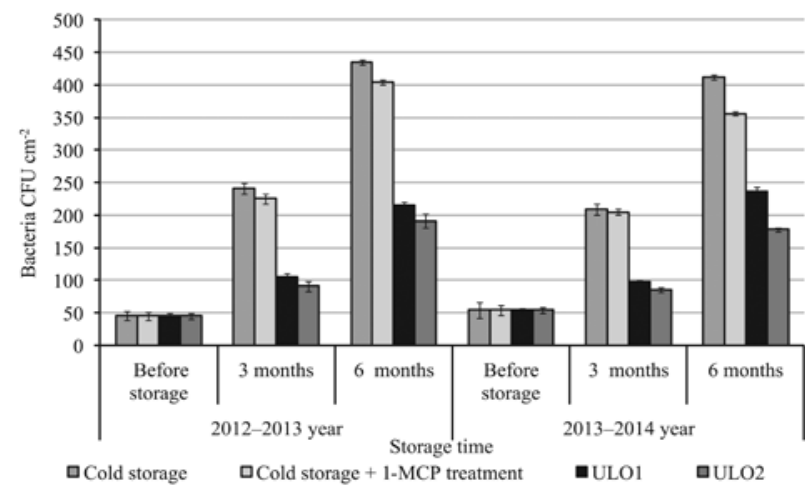

$\mathrm{CFU}$ - colony forming units, ULO - ultra low oxygen

Figure 1. The dynamics of total plate count of bacteria on the apple surface during storage

The highest amount of bacteria after a sixmonth storage was found on the apples, which had been stored in cold storage compared with those stored in ULO chambers. This phenomenon can be explained by the fact that apple fruits that had been stored using cold storage were contaminated repeatedly during storage. This means that during fruit storage, contamination of healthy fruits commonly occurs by spores through fruit-to-fruit contact, especially if fruits are injured during harvesting (Jones, Aldwinckle, 2004).

At the end of apple storage under controlled atmosphere, the total amount of bacteria on the surface of apples was significantly $(p<0.05)$ lower (twice) compared with the microflora of the apples stored under normal atmosphere. Hence, we may conclude that in ULO environment the positive effect was achieved by suppressing the growth of aerobic bacteria, while facultative aerobic bacteria continued to multiply.

The total amount of colony forming units of yeasts on the surface of apples did not differ significantly $(p<0.05)$ between the storage treatments and research years (Fig. 2). However, the highest amount of yeasts was found on the surface of apples stored in cold storage. Assessing the results obtained in the current research

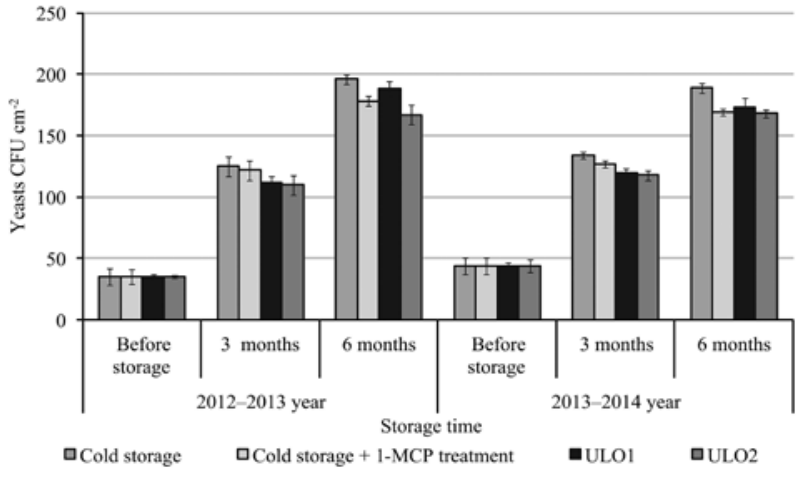

CFU - colony forming units, ULO - ultra low oxygen

Figure 2. The dynamics of total plate count of yeasts on the apple surface during storage

it can be concluded that statistically positive influence of 1-MCP treatment and ULO conditions on the yeast proliferation during the storage was not achieved. This phenomenon can be explained by the fact that yeasts are able to grow under both aerobe and anaerobe conditions. The total amount of colony forming units increased throughout the fruit storage in cold storage, as well as under controlled atmosphere in ULO (Fig. 2).

After a six months storage, the total amount of mould on apple surface was considerably $(p<0.05)$ increased and the most pronounced increasing was found on the surface of apples that had been stored in cold storage $502 \mathrm{CFU} \mathrm{cm}^{-2}$ (storage year 2012-2013) and $589 \mathrm{CFU} \mathrm{cm}^{-2}$ (storage year 2013-2014) (Fig. 3). No statistically significant differences in the number of colony forming units were observed between the cold storage and cold storage +1 -MCP treatments. However, the total plate count of mould on the surface of apples when stored under controlled atmosphere in ULO was significantly $(p<0.05)$ lower. This can be explained by the anaerobic conditions in controlled atmosphere, which delayed the development of moulds. The analysis of the data evidenced that the amount of colony forming units on apple surface under controlled atmosphere ULO1 was $103 \mathrm{CFU} \mathrm{cm}^{-2}$ (storage year 2012-2013), while in storage

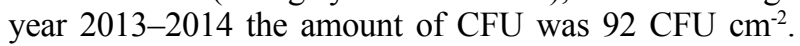
Somewhat lower, but not significantly different $(p<$ 0.05 ) amount of colony forming units was detected on the surface of apples stored in ULO2. The amount of

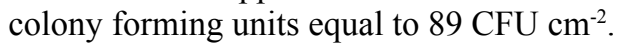

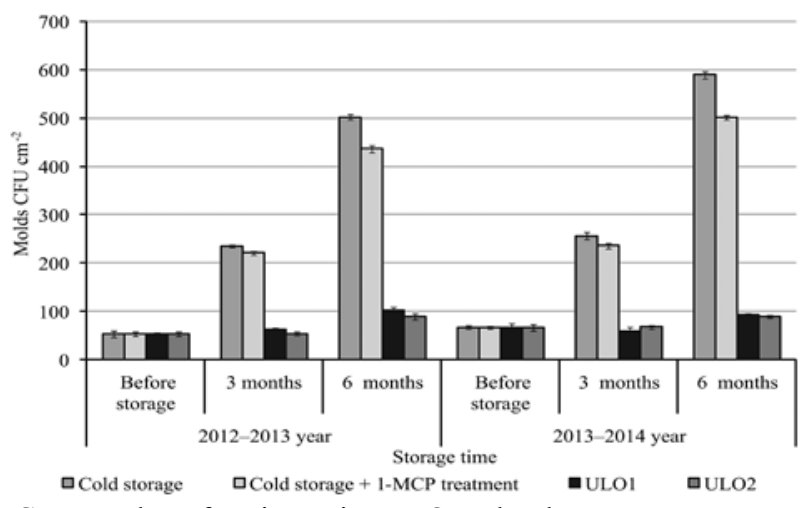

$\mathrm{CFU}$ - colony forming units, ULO - ultra low oxygen

Figure 3. The dynamics of total plate count of moulds on the apple surface during storage 
Since fruit microflora depends mainly on the storage environment and conditions, the identification of microorganisms was carried out both before and after the fruit storage. The results of research indicate that before the storage, $70 \%$ of the total microflora on the fruit surface consisted of the following microscopic fungi: Penicillium spp., Alternaria spp., Botrytis spp., Aspergillus spp., Mucor genera and Cladosporium spp., while Bacillus spp., bacteria and yeasts like Candida curvata, Candida fomata, Pichia etchellsii and Pichia carsonii. Similar observations of apple surface microflora were obtained by other scientists (Scheper et al., 2007; Juhneviča et al., 2011).

Currently, scientists pay more attention to those problems that are associated with the human health and fruit microflora that affect human health. For instance, some trials have been conducted using heat-treatment technologies aimed to decrease Escherichia coli $\mathrm{O} 157: \mathrm{H} 7$ and Salmonella muenchen population, present on the surface of apples (Wang et al., 2012).

Our observations in the current research revealed that pathogenic microflora like Escherichia spp. and Salmonella spp., which can have harmful influence on the human organism, was not detected. On the surface of apples, which were stored under normal atmosphere in cold storage, significantly lower CFU of Botrytis spp., Penicillium spp.,Alternaria spp.,Mucorspp.,Pseudomonas fluorescens, Bacillus spp., Candida curvata, C. fomata, Pichia etchellsii and P. carsonii was found. The highest amount of microorganisms was found on the surface of apples that had been stored in cold storage, compared with apples stored under controlled atmosphere.

After six months of apple storage under controlled atmosphere in ULO1, on the surface of apples the following microorganisms were identified: Penicillium, Bacillus spp., Candida curvata, Pichia etchellsii and Candida, fomata, while on the apples stored in ULO2 the following microorganism species and genera were identified: Penicillium spp., Bacillus spp., Candida curvata and C. fomata. Lower prevalence of microorganism species was found on the surface of apples stored in ULO2. During storage of apples for six months in ULO1 and ULO2, 90\% of all the microorganisms located on the surface of apples were yeasts due to their facultative anaerobe properties. The results from the current study revealed that the genus of Penicillium was also detected on apples that had been stored under controlled atmosphere conditions. Based on the literature, it became clear that some Penicillium species can grow in low-oxygen tensions. Penicillium expansum and Penicillium roqueforti are able to grow normally in $2 \%$ of oxygen. In turn, no other representatives of microscopic fungi were detected.

Based on the results obtained in this research, it can be concluded that before storage microflora of apples consisted of Penicillium genera and gas composition that had been selected, significantly reduced the proliferation of microscopic fungi, excluding Penicillium genera. The same observation was established by the researcher from Latvia (Juhneviča et al., 2011). In turn, microflora of apple surface after cold storage consisted of $85 \%$ of Penicillium spp. Based on the results in this research, it can be concluded that microflora of apple surface consisted predominantly of Penicillium spp., which prevented the development of other microscopic fungi.

\section{Conclusions}

1. The highest number of colony forming units (CFU) of bacteria was observed on the surface of apples stored for six months in cold storage and those stored in cold storage +1 -methylcyclopropene (1-MCP) treatment, while the lowest on fruits stored in controlled atmosphere (ultra low oxygen, ULO).

2. The highest amount of colony forming units of moulds after a six-month storage was found on apples that had been stored in cold storage. In turn, significantly lowest $(p<0.05)$ amount of CFU was found on apples that had been stored under controlled atmosphere. Anaerobic conditions that provide ULO storage significantly suppressed the development of oxygen-dependent microorganisms.

3. At the beginning of storage, $70 \%$ of the total surface microflora on the fruits consisted of such microscopic fungi as Penicillium spp., Alternaria spp., Botrytis spp., Aspergillus spp., Mucor genus, and Cladosporium spp., bacteria from Bacillus genus, and yeasts like Candida curvata, C. fomata, Pichia etchellsii and $P$. carsonii.

4. During six months of cold storage, on the surface of apples a vast majority of the above mentioned microorganisms along with Pseudomonas fluorescens were detected. At the same time, on the surface of fruits stored in controlled atmosphere considerably lower amount of microorganisms was found compared with the control samples. Penicillium spp., Bacillus spp., Candida curvata, Pichia etchellsii and C. fomata were identified on the surface of apples stored in ULO1, while on those apples stored in ULO2 samples only Penicillium spp., Bacillus spp., Candida curvata and C. fomata were detected.

\section{Acknowledgments}

This research has been prepared within National Research Programme No. 2010.10-4/VPP-5 "Sustainable use of local resources (entrails of the earth, food, and transport) - new products and technologies (NatRes)" (2010-2013). National Research Programme No. 10-4/ VPP-7/3 “Agricultural Resources for Sustainable Production of Qualitative and Healthy Foods in Latvia (AgroBioRes)".

Received 18012016

Accepted 08042016

\section{References}

Aithal S. C. 2009. Air microbiology. Parbhani, India, p. 1-13 http://www.scribd.com/doc/19079015/Air-Microbiology2009\#scribd

Barta J. 2006. Fruit processing plant. Hui Y. H. et al. (eds.). Handbook of fruits and fruit processing. p. 231-245 http://dx.doi.org/10.1002/9780470277737.ch14

Barth M., Hankinson T. R., Zhuang H., Breidt F. 2009 Microbiological spoilage of fruits and vegetables. Sperber W. H., Doyle M. P. (eds.). Compendium of the microbiological spoilage of foods and beverages. Food microbiology and food safetv. p. 135-183 http://dx.doi.org/10.1007/978-1-4419-0826-1

Battilani P., Barbano C., Logrieco A. 2008. Risk assessment and safety evaluation of mycotoxins in fruits. Barkai-Golan R., Paster N. (eds.). Mycotoxins in fruits and vegetables, p. $1-26$

http://dx.doi.org/10.1016/B978-0-12-374126-4.00001-2 
Beresford R. M., Kim K. S. 2011. Identification of regional climatic conditions favorable for development of European canker of apple. Phytopathology. 101 (1): 135-146 http://dx.doi.org/10.1094/PHYTO-05-10-0137

Henney J. E., Taylor C. L., Boon C. S. 2010. Preservation and physical property roles of sodium in foods. Henney J. E. (ed.). Strategies to reduce sodium intake in the United States, p. 91-119

http://dx.doi.org/10.17226/12818

Jones A. L., Aldwinckle H. S. 2004. Compendium of apple and pear diseases, p. 15-60

Juhneviča K., Skudra G., Skudra L. 2011. Evaluation of microbiological contamination of apples stored at modified atmosphere. Environmental and Experimental Biology, 9 (1-2): 53-59

Karvala K., Nordman H., Luukkonen R., Nykyri E., Lappalainen S., Hannu T. Toskala E. 2008. Occupational rhinitis in damp and moldy workplaces. American Journal of Rhinology, 22: 57-462 http://dx.doi.org/10.2500/ajr.2008.22.3209

Lampel K. A., Al-Khaldi S., Cahill S. M. 2012. Factors that affect microbial growth in food. Lampel K. A. et al. (eds.). Handbook of foodborne pathogenic microorganisms and natural toxins, p. 262-264

Lignell U., Meklin T., Putus T., Rintala H., Vepsäläinen A., Kalliokoski P., Nevalainen A. 2007. Effects of moisture damage and renovation on microbial conditions and pupils' health in two schools - a longitudinal analysis of five vears. Journal of Environmental Monitoring, 9: 225$233 \mathrm{http} / / / \mathrm{dx}$. doi.org/10.1039/B615459J

Łukaszuk C., Krajewska-Kułak E., Guzowski A., Kraszyńska B., Grassmann M., Dobrowolski R. 2015. Analysis of the incidence fungi in a crypt cemetery. Journal of the Air and Waste Management Association. 65 (9): 1141-1147 http://dx.doi.org/10.1080/10962247.2015.1068884

Oranusi U. S., Wesley B. 2012. Microbiological safety assessment of apple fruits (Malus domestica Borkh) sold in Owerri Imo State Nigeria. Advance Journal of Food Science and Technology, 4 (2): 97-102

Rodrigo M.-J., Alquézar B., Alférez F., Zacarías L. 2012. Biochemistry of fruits and fruit products. Sinha N. et al. (eds.). Handbook of fruits and fruit processing, p. 13-35 http://dx.doi.org/10.1002/9781118352533.ch2

Scheper R. W. A., Rogers D. J., Walker J. T. S., Manning M. A., Wood P. N. 2007. The incidence of storage rots after postharvest apple washing. New Zealand Plant Protection, 60: 7-14

Tapia M. S., Alzamora S. M., Chirife J. 2007. Effects of water activity (aw) on microbial stability: as a hurdle in food preservation. Barbosa-Canovas G. V. et al. (eds.). Water activity in food, p. 239-273 http://dx.doi.org/10.1002/9780470376454.ch10

Wang H., Zhou B., Feng H. 2012. Surface characteristics of fresh produce and their impact on attachment and removal of human pathogens on produce surfaces. Gomez-Lopez M. V. (ed.). Decontamination of fresh and minimally processed produce. p. 43-59 http://dx.doi.org/10.1002/9781118229187.ch2

Wawrzynczak A., Jozwiak Z., Rutkowski K. 2007. The influence of storage conditions and 1-MCP treatment on ethylene evolution and fruit quality in 'Gala' apple. Vegetable Crops Research Bulletin, 66: 188-196 http://dx.doi.org/10.2478/v10032-007-0021-9

ISSN 1392-3196 / e-ISSN 2335-8947

Zemdirbyste-Agriculture, vol. 103, No. 2 (2016), p. 215-220

DOI $10.13080 /$ z-a.2016.103.028

\title{
Apdorojimo 1-MCP ir laikymo sąlygu įtaka mikroorganizmų vystymuisi ant Latvijoje užaugintų obuolių paviršiaus
}

\author{
K. Juhnevica-Radenkova, V. Radenkovs, D. Seglina \\ Latvijos žemès ūkio universiteto Sodininkystès ir daržininkystės institutas
}

\begin{abstract}
Santrauka
Vaisių kokybè sandèliavimo metu priklauso nuo sandèlio aplinkos ir vaisių mikroorganizmų, nes jie gali sukelti vaisių puvini. Tinkamai parinkta duju mišinio obuoliu laikymo kameroje sudètis gali pailginti vaisių vartojimo laiką sumažindama mikroorganizmų vystymąsi ir užtikrindama vaisių mikrobiologinę saugą. Tyrimo tikslas ìvertinti mikrofloros ant obuolių paviršiaus dinamiką per 6 laikymo šaltai mènesius, prieš tyrimą vaisius apdorojus 1-metilciklopropenu (1-MCP) ir ant obuoliu, laikomų esant itin mažai deguonies koncentracijai skirtingomis kontroliuojamos atmosferos sąlygomis. Didžiausia mikrobų ịvairovè ir kiekis ant obuolių paviršiaus buvo laikant šaltai. Laikymo pradžioje $70 \%$ visos obuoliu paviršiaus mikrofloros sudare Penicillium spp., Alternaria spp., Botrytis spp., Aspergillus spp. bei Mucor genties mikroskopiniai grybai, Cladosporium spp. bei Bacillus genties bakterijos ir Candida curvata, C. fomata, Pichia etchellsii bei P. carsonii mielès. Po obuolių laikymo 3 ir 6 mènesius buvo nustatytas mikroorganizmų slopinimas, lyginant jų laikymą šaltai ir laikymą šaltai + apdorojimą 1-MCP, o didžiausias teigiamas esminis rezultatas buvo gautas obuolius laikant kontroliuojamos atmosferos sąlygomis. Po 6 mènesių laikymo mažiausias kiekis bakterijų, pelèsių ir mielių kolonijas formuojančiu vienetų buvo nustatytas ant paviršiaus obuolių, laikytų kontroliuojamos atmosferos sąlygomis. Mikroorganizmai Penicillium, Bacillus spp., Candida curvata, Pichia etchellsii ir C. fomata ant obuoliu paviršiaus buvo nustatyti mažos deguonies koncentracijos 1 variante, o 2 variante buvo nustatyti tik Penicillium spp., Bacillus spp., C. curvata ir C. fomata. Po laikymo kontroliuojamos atmosferos sąlygomis 90 \% visų mikroskopinių grybų, esančių ant obuolių paviršiaus, buvo mielès.
\end{abstract}

Reikšminiai žodžiai: kontroliuojama atmosfera, laikymo technologijos, mikroorganizmai, paviršius.

Please use the following format when citing the article:

K. Juhnevica-Radenkova, V. Radenkovs, D. Seglina. 2016. Influence of 1-MCP treatment and storage conditions on the development of microorganisms on the surface of apples grown in Latvia. Zemdirbyste-Agriculture, 103 (2): 215-220 DOI 10.13080/z-a.2016.103.028 